\title{
Canadian Experience in the Application of Paste and Thickened Tailings for Surface Disposal
}

\author{
J. Oxenford John Oxenford and Associates, Canada
}

E.R. Lord Syncrude Canada Ltd, Canada

\section{INTRODUCTION}

Canada has long been one of the world's major mining centres and has been at the forefront in the development and application of paste and thickened tailings technology for surface disposal of fine-grained tailings waste. In 1973 under the guidance of Dr. E. Robinsky, the first thickened tailings operation for surface disposal was inaugurated at the Kidd Operation in Ontario. Over the years, thickening improvements have been implemented and today Kidd ranks as the longest operating thickened tailings surface disposal site in the world.

Other commercial operations followed. For example, in 1981 the Line Creek Coal Mine in British Columbia was commissioned with "solid" tailings management. A thickener/filter combination dewaters the fine tailings to a cake, which is then co-disposed with a coarser fraction of mine waste in stable dumps. This approach avoided the need for a tailings pond. The Jonquière alumina refinery in Québec introduced thickeners and "mud stacking" in 1987 enabling the conversion of existing "wet" ponds to "dry" storage areas. In 1995, a thickener was added at the Cluff Lake Uranium Mine in Saskatchewan thereby extending the life of the tailings management area, which until then used a conventional tailings pond approach. In 1998, the Ekati Mine - the first diamond mine in Canada - was commissioned in the North West Territories incorporating thickeners to optimize water recovery and produce a dense tailings underflow. In 2003, the Muskeg River Mine in Alberta's oil sands commissioned thickeners with the objective of more rapid water recovery. Also in 2003, the Myra Falls Mine in British Columbia commissioned a plant which produced a thickened tailings slurry by combining thickener underflow with a portion that had been filtered. This initiative enabled the conversion of existing tailings ponds into a thickened tailings disposal area, thereby extending the mine life through increased solids storage.

These Canadian examples (Table 1) illustrate the application of paste and thickened tailings for surface disposal of fine grained tailings waste both in greenfield and retrofit situations. The economic/engineering and environmental/social benefits were site specific. 
Table 1 Canadian examples of paste and thickened tailings for surface disposal

\begin{tabular}{|c|c|c|c|c|c|}
\hline $\begin{array}{l}\text { Operation } \\
\text { - P\&TT } \\
\text { start date }\end{array}$ & Industry & Thickener & $\begin{array}{l}\text { Deposit } \\
\text { volume } \\
(2005)\end{array}$ & $\begin{array}{c}\text { Deposit } \\
\text { slope }\end{array}$ & Notes \\
\hline $\begin{array}{l}\text { Kidd } \\
-1973 \\
\text { (greenfield) }\end{array}$ & $\begin{array}{l}\text { Zinc } \\
\text { /copper }\end{array}$ & $\begin{array}{l}\text { Outokumpu (1) } \\
35 \text { m diameter, } \\
\text { elevated, } \\
\text { external }\end{array}$ & $\approx 50 \mathrm{M} \mathrm{m}^{3}$ & $1.5 \%$ & $\begin{array}{l}\text { Outokumpu thickener } \\
\text { installed in 1995. Lime } \\
\text { addition }\end{array}$ \\
\hline $\begin{array}{l}\text { Line Creek } \\
\text { - 1981 } \\
\text { (greenfield) }\end{array}$ & Coal & $\begin{array}{l}\text { Enviroclear (1) } \\
17.1 \text { m diameter, } \\
\text { elevated, internal }\end{array}$ & $\begin{array}{c}\text { Not } \\
\text { applicable }\end{array}$ & - & $\begin{array}{l}\text { Co-disposal of filtered } \\
\text { thickener underflow with } \\
\text { coarse reject }\end{array}$ \\
\hline $\begin{array}{l}\text { Jonquière } \\
-1987 \\
\text { (retrofit) }\end{array}$ & $\begin{array}{l}\text { Aluminium } \\
\text { /bauxite }\end{array}$ & $\begin{array}{l}\text { Alcan deep bed } \\
12 \text { m diameter, } \\
\text { elevated, internal }\end{array}$ & $\approx 15 \mathrm{M} \mathrm{m}^{3}$ & $3-4 \%$ & $\begin{array}{l}\text { Pipeline below deposit. } \\
\text { Last thickener in series } \\
\text { discharges to tailings area }\end{array}$ \\
\hline $\begin{array}{l}\text { Cluff Lake } \\
-1995 \\
\text { (retrofit) }\end{array}$ & Uranium & $\begin{array}{l}\text { EIMCO }(1) \\
25.9 \text { m diameter, } \\
\text { elevated, } \\
\text { external }\end{array}$ & $\approx 1.3 \mathrm{M} \mathrm{m}^{3}$ & $3 \%$ & $\begin{array}{l}\text { Mine and thickener } \\
\text { operation closed } \\
\text { December } 2002\end{array}$ \\
\hline $\begin{array}{l}\text { Ekati } \\
-1998 \\
\text { (greenfield) }\end{array}$ & Diamond & $\begin{array}{l}\text { E-CAT (2) } \\
12 \text { m diameter, } \\
\text { elevated, internal }\end{array}$ & $\approx 10 \mathrm{M} \mathrm{m}^{3}$ & $1 \%$ & $\begin{array}{l}\text { Deposition into existing } \\
\text { lake }\end{array}$ \\
\hline $\begin{array}{l}\text { Muskeg River } \\
\text { - } 2003 \\
\text { (greenfield) }\end{array}$ & Oil sands & $\begin{array}{l}\text { EIMCO (2) } \\
90 \text { m diameter, } \\
\text { inground, } \\
\text { external }\end{array}$ & $\begin{array}{c}\text { Not } \\
\text { known }\end{array}$ & - & $\begin{array}{l}\text { Thickeners installed } \\
\text { primarily for water } \\
\text { recovery }\end{array}$ \\
\hline $\begin{array}{l}\text { Myra Falls } \\
-2003 \\
\text { (retrofit) }\end{array}$ & $\begin{array}{l}\text { Zinc } \\
\text { /copper }\end{array}$ & $\begin{array}{l}\text { Outokumpu (1) } \\
25 \text { m diameter, } \\
\text { elevated, } \\
\text { external }\end{array}$ & $\begin{array}{c}\text { Not } \\
\text { known }\end{array}$ & $3 \%$ & $\begin{array}{l}\text { Portion of thickener } \\
\text { underflow is filtered. } \\
\text { Filter cake is then mixed } \\
\text { with thickener underflow } \\
\text { to form pumpable high } \\
\text { density slurry }\end{array}$ \\
\hline
\end{tabular}

\section{EXAMPLES}

\section{$2.1 \quad$ Zinc/copper industry}

The Kidd Zinc/Copper Operation is located about $25 \mathrm{~km}$ east of Timmins, Ontario. It was the first to utilize thickened tailings for surface disposal in Canada and has been in operation since 1973. A thickened tailings concept was selected in preference to a conventional tailings pond for a number of reasons, primarily because the foundation glacial soils had low strength and could not support containment structures higher than $3 \mathrm{~m}$, the fines grind in the mill resulted in all the tailings (silt and clay size) not being suitable for hydraulic dam construction and a scarcity of construction gravel.

Thickener operating experience has progressed over the years and in 1995 the existing thickener was replaced by an elevated Outokumpu $35 \mathrm{~m}$ diameter high rate thickener with $4 \mathrm{~m}$ vertical wall and open top. Zinc and copper concentrator tailings (solids $\mathrm{SG}=3.1$ ) are pumped to the thickener which is located in the tailings management area. The thickener is located outside and fully exposed to the severe Canadian winter 
environment. Thickener overflow, as well as water seepage from the deposit and rainfall, flows around the deposit perimeter to a collection pond. About half the water is reused in the plant with excess being treated and released into a nearby river (Robinsky, 1999 and 2000).

Thickener underflow is pumped using centrifugal pumps, through a $406 \mathrm{~mm}$ diameter HDPE surface pipeline, $1.1 \mathrm{~km}$ to a lime addition station at the deposit. Lime is added when required to increase the thickened tailings viscosity and hence the resulting deposit slope. Thickened tailings are centrally discharged (single point) off a berm at a targeted $63 \%$ solids by weight. The deposit builds up at a rate of about $120 \mathrm{~mm}$ depth a year with a $2 \%$ slope and continues to consolidate, ultimately reaching $80 \%$ solids by weight. The deposit is about $2 \mathrm{~km}$ in diameter, $25 \mathrm{~m}$ deep at the centre with an average depth of $4.2 \mathrm{~m}$ (Figure 1). It covers 1200 hectares and contains over 100 M tonnes (Sudbury, 1999 and Lucciatonio, 2000).

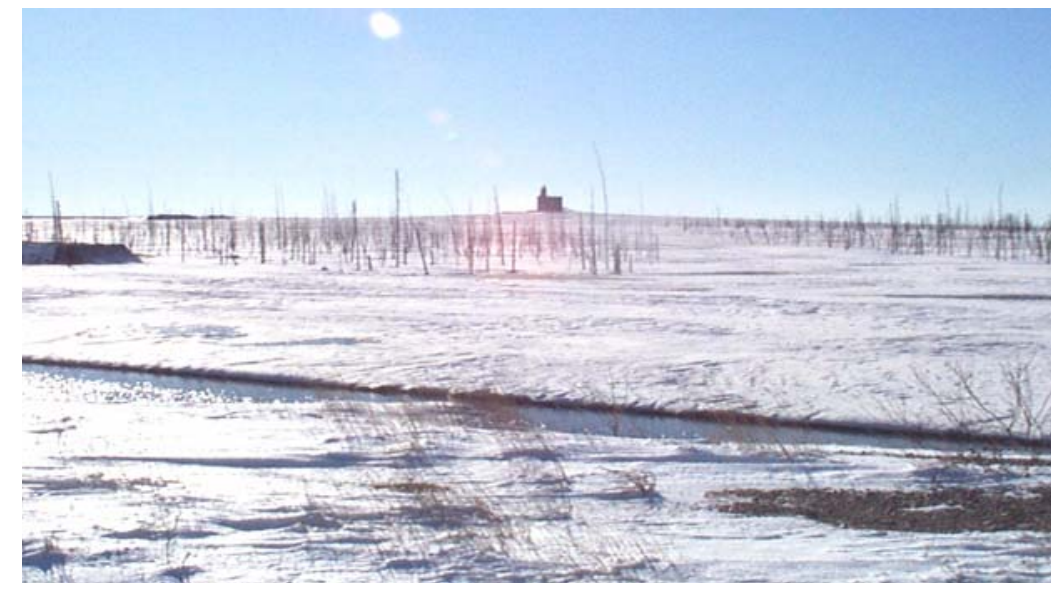

\section{Figure 1 Thickened tailings deposit at the Kidd zinc/copper operation}

The Kidd Operation initially failed to achieve design slopes, primarily because the thickeners available at the time could not provide the desired underflow density. The operators have persevered and over the years have progressed thickened tailings for surface disposal through improvements to thickener design and operating procedures.

The Myra Falls Zinc/Copper Mine is located about $90 \mathrm{~km}$ southwest of Campbell River, British Columbia. Since startup in 1966, the operation had used a conventional tailings pond approach. However, it became apparent that tailings disposal would have limited the life of the mining operation unless the settling area was expanded or better utilized for tailings storage. Seeking regulatory approval for an expansion of a conventional tailings operation in a Provincial Park, was not an attractive option. It was decided that rather than close the mine down, to convert the tailings management area from "wet" ponds to "dry" ponds and thereby increase tailings storage volume. Thickening and partial filtration of thickener underflow with subsequent recombining and sub-aerial disposal was adopted. The key driver was continued operation of the mine. 
Cyclone overflow (solids $\mathrm{SG}=3.6$ ) from the concentrator mill is pumped to an externally located elevated Outokumpu $25 \mathrm{~m}$ diameter thickener. A portion of the thickener underflow (55\% solids by weight) is pumped using centrifugal pumps to an internally located Dorr-Oliver Eimco $3.2 \mathrm{~m}$ diameter 12 disc vacuum filter. The filter increases the density to approximately $70-75 \%$ solids by weight. The filter cake is then mixed with the remaining thickener underflow and the resulting slurry (in the 65-68\% solids by weight range) is pumped using positive displacement pumps to the disposal area which has been created on top of the original tailings pond. Single point sub-aerial discharge at the deposit perimeter results in a slope reported to be $3 \%$ (Figure 2). Water recovered water from the thickener, filter and deposit is reused in the plant with the excess being treated and released into a nearby river.

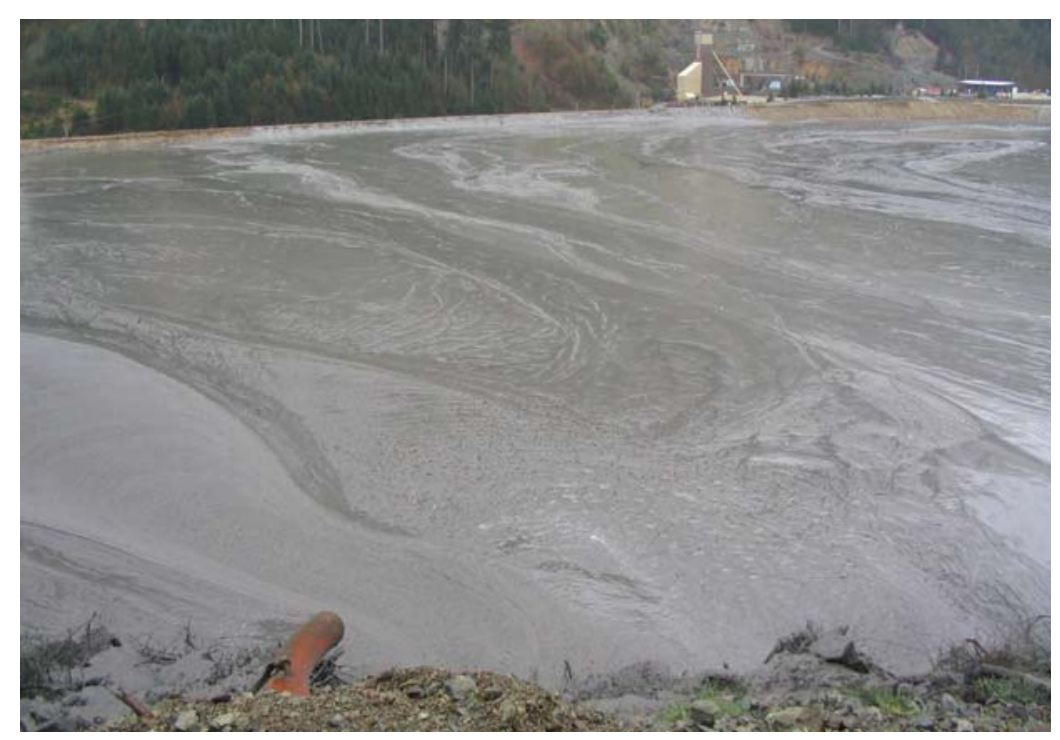

\section{Figure 2 Thickened tailings deposit at the Myra Falls zinc/copper mine}

Myra Falls is a good example of a retrofit initiative, converting existing tailings ponds into a thickened tailings deposit thereby extending the mine life.

\subsection{Coal industry}

The Line Creek Coal Mine, located $27 \mathrm{~km}$ north of Sparwood in British Columbia was commissioned in 1981. A decision was made in the late 1970 's to design the mine without a tailings pond because "dry" rather than "wet", disposal was determined to have a lower overall cost.

A single elevated EnviroClear $17.1 \mathrm{~m}$ diameter thickener was selected and is located inside a building. The thickener feed $(<150 \mu \mathrm{m}$ particle size) is fine coal (solids $\mathrm{SG}=1.3$ ) and clay (solids $\mathrm{SG}=2.7$ ) from flotation cells. The thickener is fully integrated with the plant and overflow is reused immediately in the process.

Thickener underflow at a density of about $30-36 \%$ solids by weight, is pumped using a variable speed centrifugal pump to a distributor tank. From the distributor tank the thickener underflow is transferred to Andritz Type S-7 continuous belt filters ( $2.4 \mathrm{~m}$ wide porous belt). The feed lines to the filters are equipped 
with in-line static mixers where additional flocculent is added. These mixers contact and keep the aggregated solids in suspension such that free water is minimized at the feed introduction to the filters. The filter cake is discharged onto a conveyor belt and transported to the co-disposal hopper bin. The filtrate is collected and re-circulated to the thickener.

Filtered tailings and the coarse reject fraction (centrifuged to about 8\% water content, 50-64 mm lump size) from the Thermal Plant and Metallurgical Plant, are combined and conveyed to the co-disposal hopper. The combined material is trucked from the hopper to the permanent disposal area, off loaded and pushed by dozer over the crest of the waste dump. The waste dump height is approximately $40 \mathrm{~m}$ with a dump face angle of approximately 45 degrees (Figure 3).

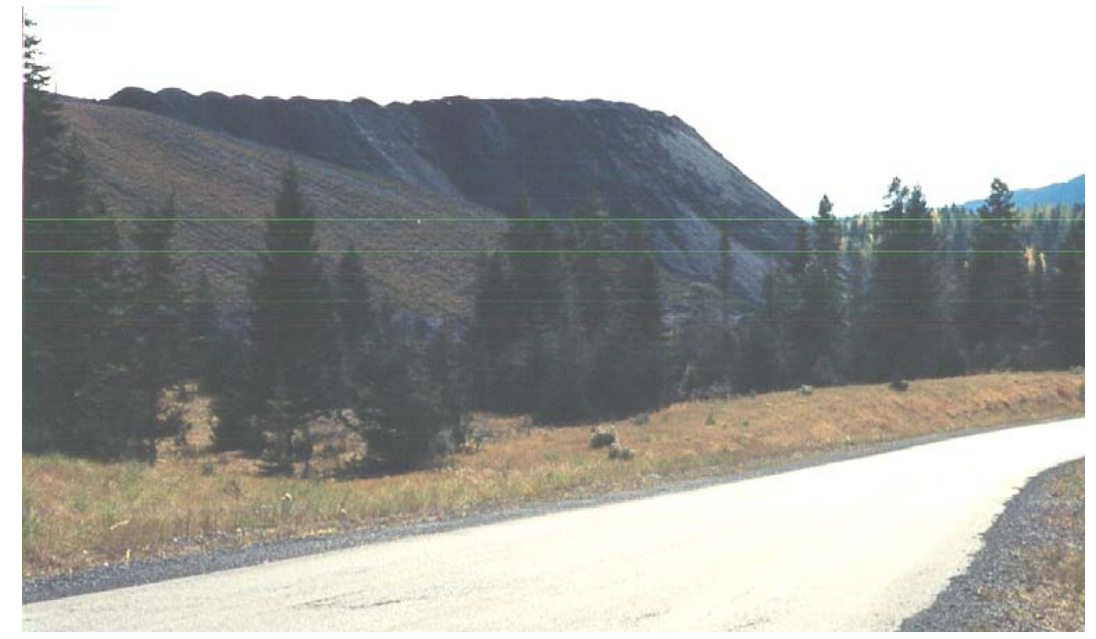

\section{Figure $3 \quad$ Waste dump at the Line Creek coal mine}

The Line Creek Coal Mine is a good example of the direct integration into plant operations of a thickener and belt filter and the subsequent co-disposal of filter cake with coarse rejects in waste dumps. A tailings pond was avoided.

\subsection{Aluminium industry}

The Jonquière Alumina Refinery, in Québec, processes bauxite (up to six different types from around the world) producing a red mud slurry waste. The plant has been in operation since 1942 and until 1987, the red mud slurry was disposed of in tailings ponds. In 1987 the operation was converted to a "mud stacking" method, building the new red mud stack over the existing tailings ponds footprint. Business drivers that supported the "mud" stacking approach were the recovery of hot solution containing alumina and sodium hydroxide and increased storage efficiency in the tailings management area.

Red mud slurry is passed through internally located thickeners in series to recover liquid in the form of hot solution containing alumina and sodium hydroxide - for reuse in the extraction process. An in-house Alcan research team developed the elevated $12 \mathrm{~m}$ diameter, $18 \mathrm{~m}$ high deep bed thickeners for "mud 
stacking”(Paradis, 1992, Belanger and Morin, 1998). The red mud slurry composition is primarily iron oxides/hydroxides - 50\%, and hydrated $\mathrm{Na}-\mathrm{Al}$ silicates (solids $\mathrm{SG}=3$ ).

Thickener underflow is pumped using positive displacement pumps ( 3 stages) to the disposal site at a density of about $45 \%$ solids by weight. The pipeline is located beneath the deposit and rises vertically to the surface for a central discharge approach. The thickened red mud slurry possesses a high yield point and at the disposal site forms sloped deposits (3-4\%). After one year of consolidation, the deposit density reaches about $68 \%$ solids by weight (Couture, 1998).

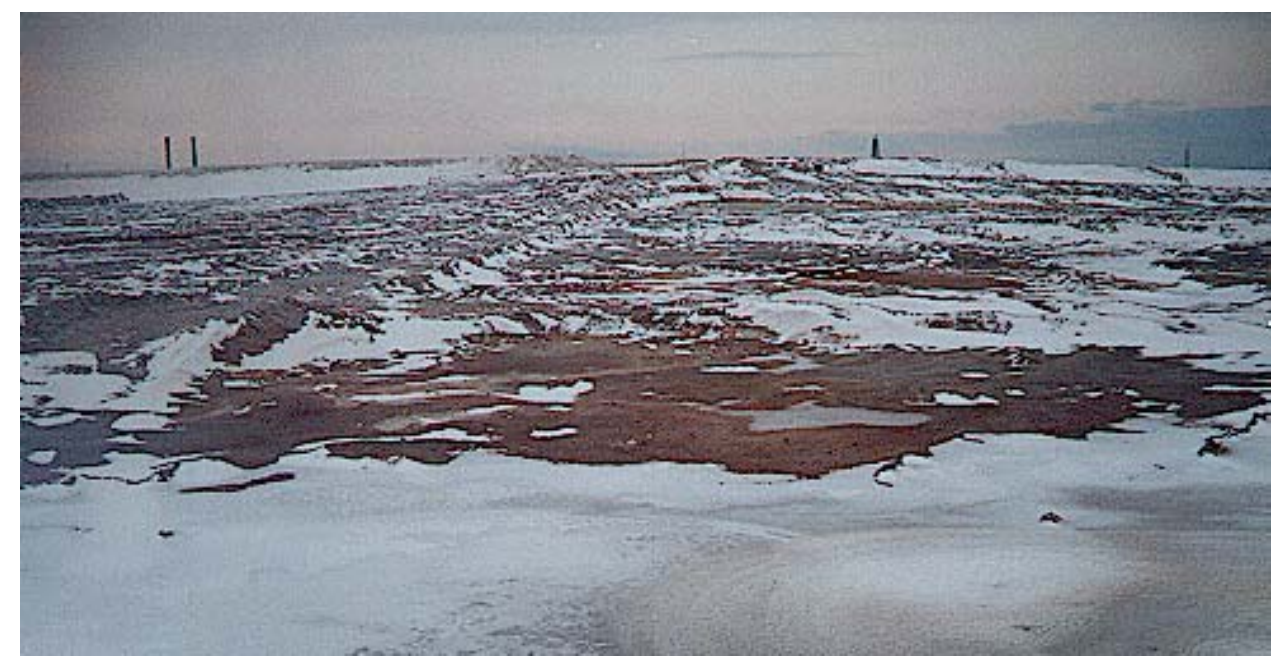

\section{Figure 4 Freeze-thaw densification of red muds at the Jonquière alumina refinery}

After a freeze-thaw cycle, the deposit density is further increased (Figure 4). The deposit is $40 \mathrm{~m}$ deep in the centre. The site covers 116 hectares and about $700000 \mathrm{~m}^{3} / \mathrm{yr}$ is deposited. Berms up to $20 \mathrm{~m}$ high contain the red mud. Seepage water is collected and recirculated back to the plant. (Paradis, 1992, Belanger and Morin, 1998, Paradis, 1999).

\section{$2.4 \quad$ Uranium industry}

The Cluff Lake Uranium Mine is located about $250 \mathrm{~km}$ north of La Loche in Saskatchewan. Commercial production began in 1981 with tailings ponds and ceased operation in 2003. It was estimated that the tailings management area would be full before the end of mine life and tailings management alternatives had to be evaluated. In order to extend the life of the operation a thickened tailings concept incorporating a high density thickener was chosen as being the most practical and economic (Nguyen and Doell, 1996).

In 1995, an elevated EIMCO 25.9 m diameter high density thickener with a $3.5 \mathrm{~m}$ high side wall was installed and operated until 2003. It was constructed of mild steel with an elevated concrete bottom at a 17\% slope. The thickener was located outside and fully exposed to the severe Canadian winter environment, with the lower part insulated by earth fill. The tailings feed to the thickener was a combination of streams derived from the grinding and milling of uranium ore to produce a concentrate of Uranium Oxide. The tailings solids 
(solids $\mathrm{SG}=2.7$ ) consisted primarily of quartz, illite and gypsum - a precipitate from the mill process. The tailings would be classified as silt and fine to medium sand (Goulden et al., 1998). Thickener overflow was pumped to the Primary Treatment System to allow chemical precipitates to settle and the clean water was discharged through a nearby lake. If required, a secondary treatment system (additional chemical addition) was used to bring the water up to discharge specification. The runoff water from the thickened tailings deposit was collected and pumped directly to the environment or Primary Treatment System. Cluff Lake Mine operated as a once through water management strategy and did not recycle water.

The thickener underflow pumps were housed in a readily accessible maintenance-friendly chamber beneath the bottom of the thickener. The thickener underflow at a density of about $52 \%$ solids by weight was pumped to the tailings management area using a hydraulic drive positive displacement piston Geho pump. The 1.7 $\mathrm{km}$ long surface tailings line was constructed of $150 \mathrm{~mm}$ diameter steel pipe with the last $200 \mathrm{~m}$ being 150 mm HDPE Schlair pipe (Nguyen and Doell, 1996). There was also a standby centrifugal pump in the chamber below the thickener. However, use of the centrifugal pump reduced the density from 52 to $49 \%$ because of dilution from gland water. Thickened tailings was discharged at a temperature of $15-20^{\circ} \mathrm{C}$ and formed a slope of about 3\% (Figure 5). In December 2002, the mill closed down and is in the process of being decommissioned. In total $2.35 \mathrm{M}$ tonnes of thickened tailings were placed at an average density of $52 \%$ solids by weight.

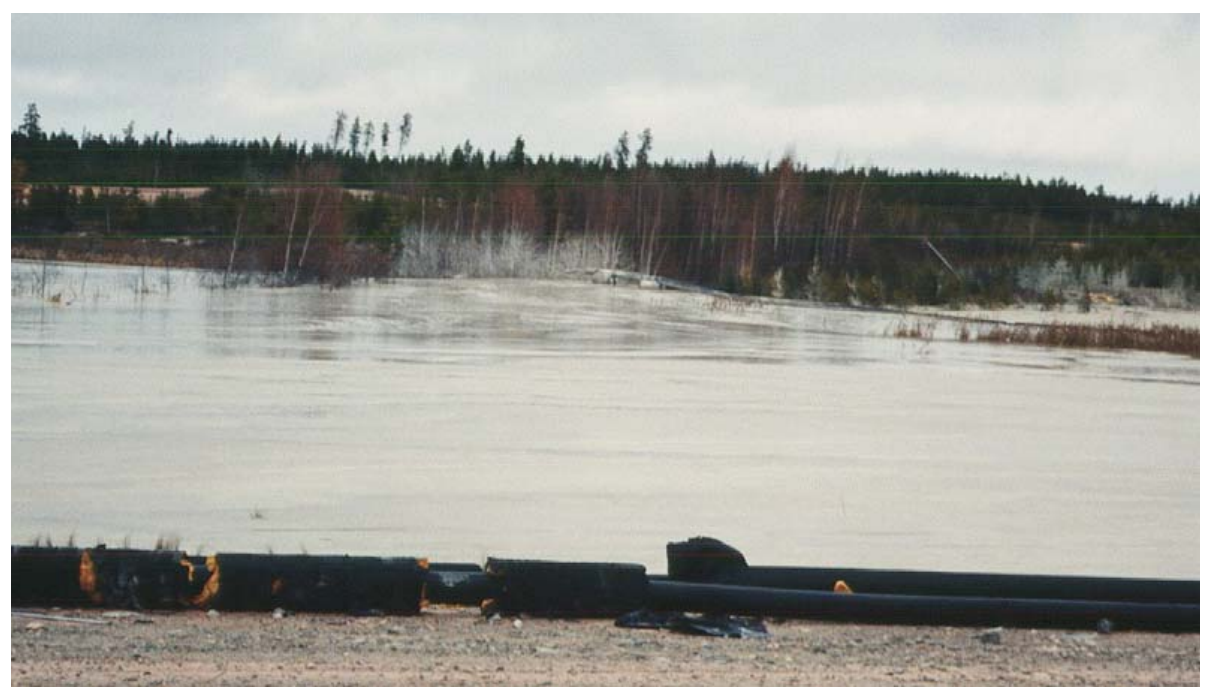

\section{Figure 5 Thickened tailings deposit at the Cluff Lake uranium mine}

Reclamation of the thickened tailings deposit is scheduled to incorporate a $1 \mathrm{~m}$ sandy clay (local till material) cover. The cover material will be delivered by 50 tonne trucks and pushed into place with 50 tonne dozers onto the thickened tailings deposit. This reclamation technique was applied to the much lower strength slimes produced from the conventional segregating tailings. The Cluff Lake Mine is a good example of the successful retrofit application of thickened tailings to an existing conventional tailings operation. The increased storage efficiency enabled the mine life to be extended by several years. 


\subsection{Diamond industry}

The Ekati Mine opened in 1998 and is located $350 \mathrm{~km}$ northeast of Yellowknife in the North West Territories. It was designed for thickened tailings disposal at the outset. Perceived advantages for the thickeners selected were small footprint for internal housing, high capacity per unit area and no moving parts.

Two internally located elevated E-CAT $12 \mathrm{~m}$ diameter thickeners, $17.5 \mathrm{~m}$ high with a 60 degree cone bottom are used to recover water and produce thickened tailings (Zaradic, 1999, Mohns and Paradis, 1999). Thickener feed $(<500 \mu \mathrm{m})$ is derived from the primary and secondary degritting units. The clay minerals include montmorillonite (solids $S G=2.7$ ). A coagulant/flocculent addition strategy results in very clean thickener overflow, supplying about $90 \%$ of the water required for the operation.

Thickener underflow at about $45 \%$ solids by weight, is pumped using variable speed centrifugal pumps to an agitated tailings holding tank. The thickened tailings are diluted with water to a density of $40 \%$ solids by weight for easier pumping (Mohns and Paradis, 1999). The tailings disposal system comprises two parallel pumping trains, each with three centrifugal pumps. The first stage is fixed speed, while the remaining two are variable speed in order to handle the variations in thickened tailings density. The $8 \mathrm{~km}, 305 \mathrm{~mm}$ diameter surface tailings line is externally heated and insulated to maintain an operating temperature of $8^{\circ} \mathrm{C}$. Due to the discharge pressures, the first $5 \mathrm{~km}$ of the pipeline is HDPE lined carbon steel. The remaining $3 \mathrm{~km}$ is HDPE.

The current strategy is to pump the thickened tailings $8 \mathrm{~km}$ to the perimeter of a nearby lake where it is discharged sub-aerially (Figure 6). The lower part of the thickened tailings deposit is below the lake surface. The deposit slope is around $1 \%$ for summer placed tailings and about $10 \mathrm{M} \mathrm{m}^{3}$ have been deposited. The planning basis is to fill up the lake over a period of 18 to 20 years sequentially moving the discharge from north to south. Final reclamation plans are being developed.

The Ekati Mine is a good example of a recently commissioned operation using deep bed thickeners. Thickener overflow supplies about $90 \%$ of the plant water requirements. 


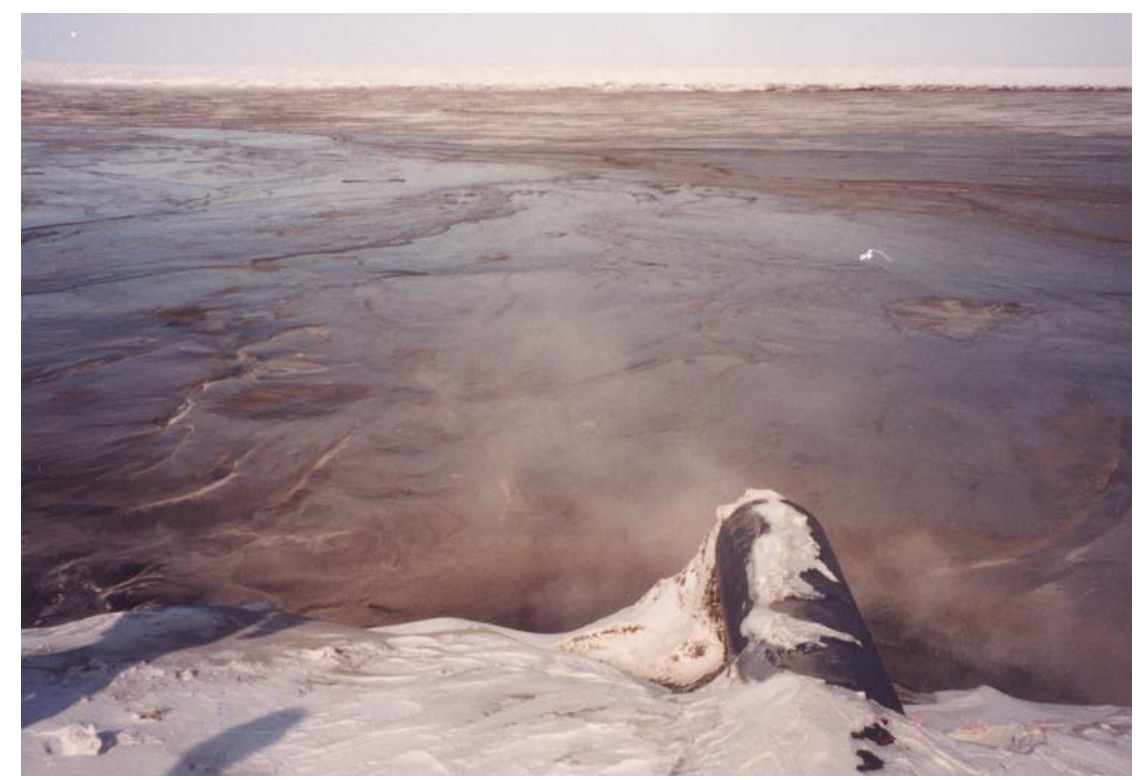

\section{Figure 6 Thickened tailings deposit at the Ekati diamond mine}

\subsection{Oil sands industry}

The surface mined component of the oil sands industry, located in the Fort McMurray area of Alberta, excavates in total about $1.5 \mathrm{M}$ tonnes per day of bituminous sand. Today this represents approximately $50 \%$ of all ore mined in Canada. The bitumen is separated from the solids using water based gravity separation techniques and then upgraded to crude oil. The remaining solids consist of relatively quick settling coarse tailings (quartz sand) and fine tailings (suspension of silt and clay) which require containment within tailings ponds. These two distinct tailings waste products - coarse (sand) tailings and fine (silt and clay) tailings are a characteristic of the oil sands industry. The volume of coarse solids is significantly higher than fine solids which provides opportunities for co-disposal tailings placement practices. This is similar to the mineral sands industry.

The oil sands industry particularly through CONRAD (Canadian Oil Sands Network for Research and Development), has collaborated on progressing new tailings initiatives principally to address the fluid nature and volume challenge of managing and storing fine tailings. Incorporation of thickeners is one option that has been extensively evaluated by the industry since 1996. This effort included a major demonstration/test (10 m diameter thickener) at the Syncrude Aurora Mine site co-sponsored by industry and government during 2001 and 2002 (Figure 7). Valuable experience was gained and shared between the participants and provided a knowledge platform for future commercial application. 


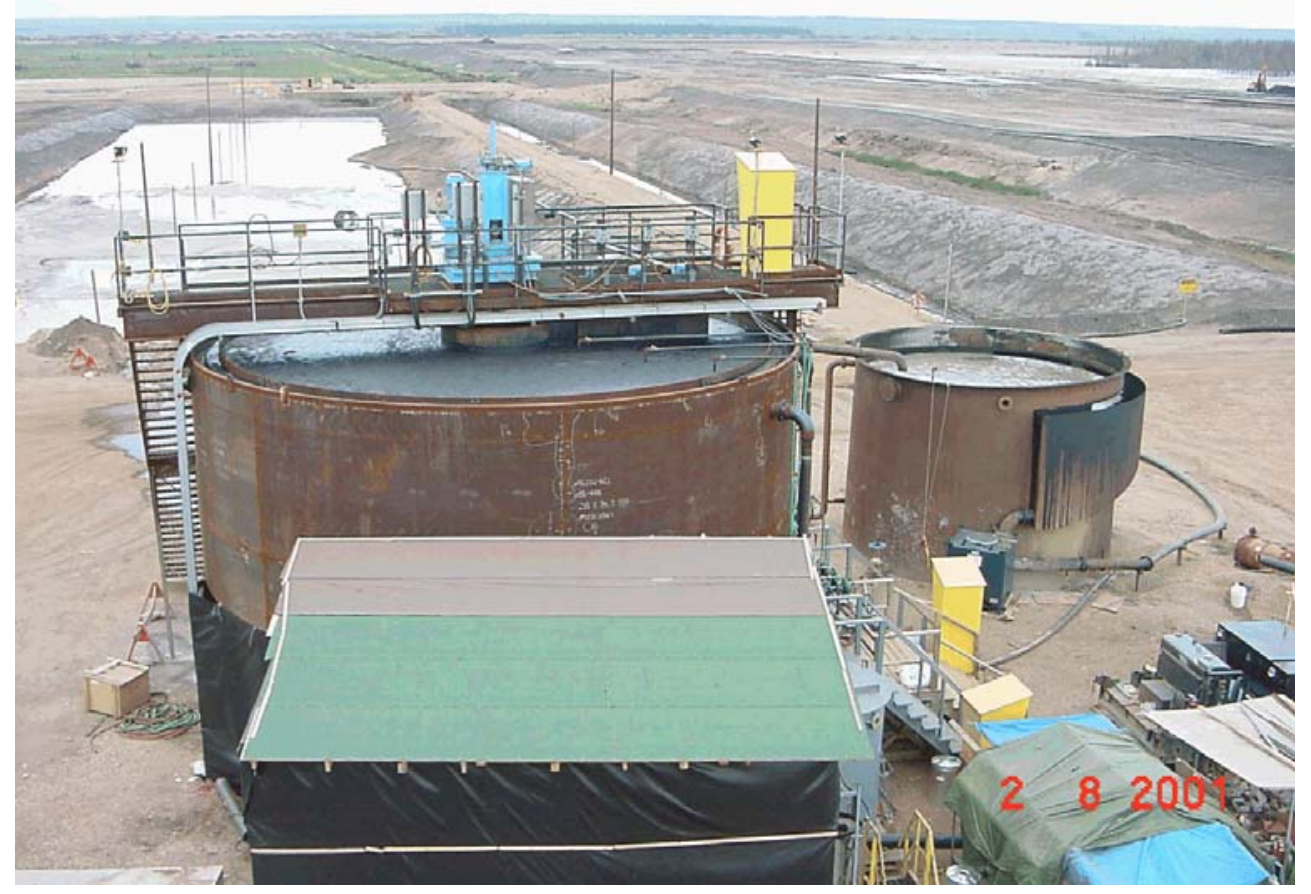

\section{Figure $7 \quad$ Thickened tailings test set-up at the Syncrude aurora mine}

In 2003, the Muskeg River Mine, located $75 \mathrm{~km}$ north of Fort McMurray, in Alberta was the first oil sands operation to incorporate thickeners. The main business drivers were the rapid recovery of warm water for reuse in the plant and for improved energy efficiency which has been the main focus of their efforts to date. Cyclone overflow from the bitumen separation plant provides the feed to two in-ground EIMCO $90 \mathrm{~m}$ diameter thickeners (Blum, 2003, Crowley, 1999, Liu et al., 2000). The thickener feed consists primarily of kaolin, illite and quartz minerals (solids $\mathrm{SG}=2.7$ ). Thickener underflow at about $25-30 \%$ solids by weight (with a sand to fines $(<44 \mu \mathrm{m})$ ratio of about $1: 1)$, is pumped to a constructed tailings pond. While currently not focused on producing thickened tailings, the operating experience will be very useful should thickeners be operated as a tailings management option. The thickeners are located outside and fully exposed to the severe Canadian winter environment.

\section{COMPARISON}

The examples are from several industries covering a range of material characteristics. For example, the thickener feed streams range from active clay minerals in the diamond and oil sands industries to inactive minerals derived from milled rock in the zinc/copper industries. The slurry densities range from 45-68\% solids by weight but caution is advised when making comparisons because of the variations in mineral specific gravity $(2.7-3.6)$. Solids by volume rather than weight would be a better number for comparison. The thickener feed particle size is generally uniformly graded with $<10 \mu \mathrm{m}$ size ranging from 20 to $65 \%$ (Figure 8). Because the oil sands tailings have a coarse and fine fraction, two different curves are shown as potential thickened tailings deposits. The flotation tailings have a significant fraction of sand whereas the 
beach runoff is devoid of the sand fraction. All the examples reported increased deposit strength resulting from dessication (through natural evaporation) even in high rainfall areas and at some locations significant freeze-thaw densification because of regional low winter temperatures. These phenomena are key to the successful implementation of this technology for surface disposal in Canada. Deposit slopes ranging from 1 to $4 \%$ are reported.

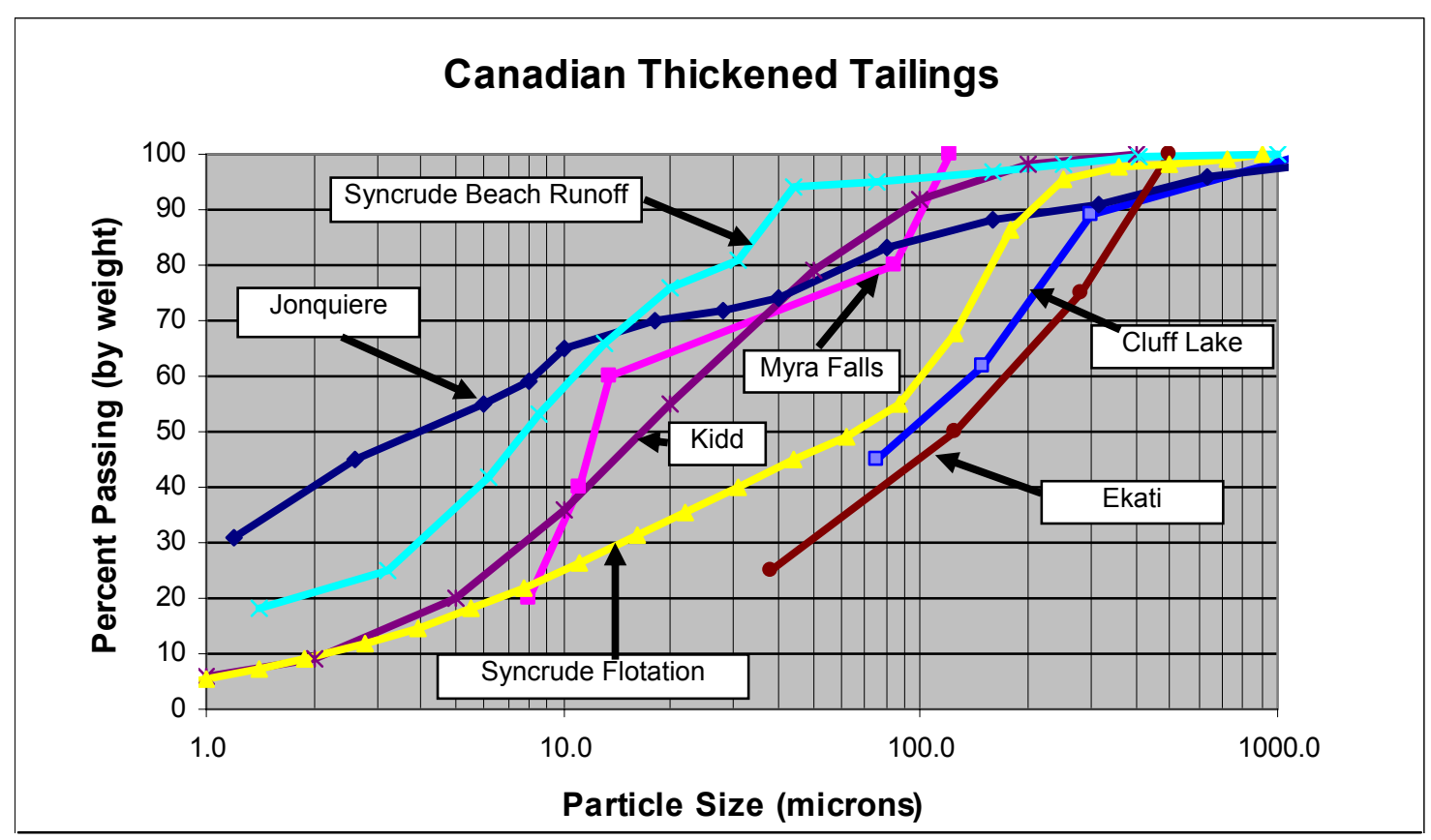

\section{Figure $8 \quad$ Particle size distribution of deposits}

In terms of business drivers, each operation has chosen to implement thickened tailings for surface disposal as a result of site specific economic/engineering and environmental/social benefits. One of the more critical business drivers was operational sustainability through increased solids storage in a specific location. There is no overall template for deciding whether to introduce the technology either in a greenfield site or as a retrofit.

\section{CURRENT R\&D DIRECTIONS}

R\&D in support of sustainable tailings management practices is at the forefront in the Canadian mining industry. For the most part, $R \& D$ is conducted by individual companies with assistance from universities and contract researchers. However for the oil sands industry, a joint industry/government/university initiative resulted in the University of Alberta establishing an Oil Sands Tailings Research Facility (OSTRF) in 2004. The OSTRF is designed for student based exploratory tailings research at the laboratory and continuous pilot scale (up to 2 tonne/hr) in support of existing and new oil sands tailings management practices. This initiative was particularly timely given the recognition that crude oil production from surface mines is expected to increase up to four times the current level of production, i.e. to $5 \mathrm{M}$ tonnes/day of oil sands mined 
over the next decade. The Alberta Chamber of Resources Technology Road Map published in 2004, identified tailings management practices as one of the major challenges for this ongoing development.

\section{CONCLUSIONS}

The application of paste and thickened tailings for surface disposal has been very successful in Canada for several different industries - in both greenfield and retrofit situations. Application will always be site specific and depend on the business drivers and in the case of retrofit, "windows of opportunity" are essential. As tailings ponds come under increasing environmental scrutiny, more and more operations are looking at the benefits of rapid water recovery and alternative tailings management practices. These include:

- Reducing the risk of a tailings incident - probability and consequence.

- Recognizing the value of recovered water.

- Reducing overall process energy costs.

- Reducing land disturbance at a given moment in time.

- Implementing progressive reclamation.

\section{ACKNOWLEDGEMENTS}

The authors gratefully acknowledge the invaluable support of Syncrude Canada Ltd for the opportunity to visit and learn from all the examples described. Thanks are also extended to the staff at the operations described who arranged for the site visits and provided unique design and operational insights.

\section{REFERENCES}

Belanger, M.J. and Morin, D. (1998) Stacking Tests at Vaudreuil Works. Proceedings International Workshop on Rehabilitation of Mined Bauxite Lands \& Red Mud Disposal Ponds, Jamaica, September 1998.

Blum, J. (2003) Albian Sands - A Case Study. International Seminar on Paste and Thickened Tailings Melbourne, Australia. May 2003.

Couture, J. (1998) Experimental Restoration of a Red Mud Stacking Site. Proceedings International Workshop on Rehabilitation of Mined Bauxite Lands \& Red Mud Disposal Ponds, Jamaica, September 1998.

Crowley, P. (1999) Research on Thickened Fine Tailings in Oil Sands. Paste Technology for Thickened Tailings Learning Seminar, Edmonton, Canada. November 1999.

Goulden, W.D., Hendry, M.J., Clifton, A.W. and Barbour, S.L. (1998) Characterization of radium-226 in uranium mill tailings. Proceedings of the Fifth International Conference on Tailings and Mine Waste '98, Fort Collins, USA. January 1998, pp. 561570.

Liu, B., Lord, E. and Krishnaumurthi, K. (2000) Depositional \& Geotechnical Properties of Thickened Oil Sands Tailings. Proceedings Transportation and Deposition of Thickened/Paste Tailings, Edmonton, Canada. October 2000.

Lucciantonio, J. (2000) Kidd Creek Mines No. 3 Tailings Thickener, Timmins, Ontario. Proceedings Transportation and Deposition of Thickened/Paste Tailings, Edmonton, Canada. October 2000.

Mohns, C.A. and Paradis, T. (1999) Deep Bed Thickener Operation at the Ekati Diamond Mine. Paste Technology for Thickened Tailings Learning Seminar, Edmonton, Canada. November 1999. 
Nguyen, T. and Doell, E. (1996) Operation of a High Density Thickener. $28^{\text {th }}$ Annual Operator's Conference of the Canadian Mineral Processors, Ottawa, Canada. January 1996, pp. 46-54.

Paradis, R.D. (1992) Disposal of Red Mud using Wet Stacking Technology. Proceedings International Bauxite Tailings Workshop, Perth, Australia. November 1992, pp. 178-186.

Paradis, R. (1999) Alcan's Paste Thickening Technology in the Alumina Undustry. Paste Technology for Thickened Tailings Learning Seminar, Edmonton, Canada. November 1999.

Robinsky, E.I. (1999) Thickened Tailings Disposal in the Mining Industry. Published by E.I. Robinsky Associates Ltd., 1 Lydia Court, Toronto, Canada M4J 5B7. November 1999.

Robinsky, E.I. (2000) Thickened Tailings Disposal (TTD) at Kidd Creek Operations, Ontario. Proceedings Transportation and Deposition of Thickened/Paste Tailings, Edmonton, Canada. October 2000.

Sudbury, M. (1999) Kidd Thickened Tailings Operation. Paste Technology for Thickened Tailings Learning Seminar, Edmonton, Canada. November 1999.

Zaradic, A.M. (1999) Ekati Diamond Mine - Engineering Challenges $101^{\text {st }}$ Annual General Meeting of the Canadian Institute of Mining, Metallurgy and Petroleum, Calgary, Canada. May 1999. 